\title{
ANAEROBIC DIGESTION OF FOOD WASTE AT VARYING OPERATING CONDITIONS
}

\author{
Bipasyana Dhungana and Sunil Prasad Lohani * \\ Department of Mechanical Engineering, Kathmandu University, Dhulikhel, Nepal
}

Article Info:
Received:
1 April 2020
Revised:
13 July 2020
Accepted:
14 July 2020
Available online:
5 October 2020
Keywords:
Anaerobic co-digestion
Food waste
Degradability
Instability
Methanogenesis

\section{INTRODUCTION}

Anaerobic Digestion (AD) is the process of decomposition of organic matter by a microbial consortium in an absence of oxygen (Sawatdeenarunat et. al., 2015; Lohani et.al., 2018). The degradation occurs in four stages, namely, Hydrolysis, Acidogenesis, Acetogenesis, and Methanogenesis. The anaerobes breakdown organic compounds to biogas that mainly consists of methane and carbon dioxide. Biogas is generally composed of $48-65 \%$ methane, $36-41 \%$ carbon dioxide, up to $17 \%$ nitrogen, < $1 \%$ oxygen, 32-169 ppm hydrogen sulphide, and traces of other gases (Gould et.al., 2015). For the successful operation of a biogas plant, it is important to understand the anaerobic digestion (AD) process, the favorable conditions in which the anaerobes thrive, and the conditions that should be maintained. A key point for the successful description of a bioprocess is the appropriate influent characterization (Huete et. al., 2006; Lohani et. al., 2016). The control of the $A D$ process is directed by the microbial activity itself (Lohani et. al., 2018).

AD of Food waste (FW) is a complex process that should simultaneously digest all the organic substrates (e.g. carbohydrate and protein) in a single-stage system (Zhang et. al., 2014). The key parameters that affect $A D$ process are temperature, volatile fatty acid (VFA), pH, ammonia, nutrients, and trace elements (Xia et.al., 2016). Proper microbial growth requires a good nutrient and trace element balance, along with a stable environment. It is therefore extremely important to maintain the appropriate range of the key parameters for the long-term operation of $A D$ (Xu \& Li, 2017; Zhang et.al., 2014). FW contains $70-80 \%$ of the water which makes it highly biodegradable (Zamanzadeh et.al., 2017). Given its high biodegradability, the management of FW through landfilling, incineration, or composting impacts the environment negatively. Alternatively, AD of FW can be the most promising cost-effective technology for renewable energy production and waste management of this energy-rich material (Morales-polo et.al., 2018; Posmanik et al., 2017).

Previous studies in the AD of FW have already established process principles, bioenergy, and waste management potential through this process (Lin et al., 2013; Zhang et al., 2014; Zhang et.al., 2013). However, adopting the AD for FW are found to pose several technical challenges such 
as accumulation of volatile fatty acids, process instability, low buffer capacity, foaming, among others. Hence, it is important to identify the current challenges in the AD of food waste (Banks et.al., 2012; Zhang et al., 2013).

FW composition and its physicochemical properties vary depending on the country, food consumption pattern, and the cultural and economic aspects (Lin et al., 2013). $\mathrm{AD}$ of FW conducted at an organic loading rate of $4.0 \mathrm{~g} \mathrm{VS} /$ (L.d) and $2.0 \mathrm{gVS} /($ L.d) resulted in high VFAs concentration and low $\mathrm{pH}$ in the digestion chamber leading to low biogas production rate ( El-Mashad et.al., 2008). In the same experiment, food waste was co-digested with dairy manure which indicated a significant increase in biogas production rate, compared to mono-digestion of food waste. In a study by Zhang et. al. (2014), the AD of FW was done for stabilizing the process in a controlled mesophilic condition by adding different quantities of lime mud, and cultured sewage sludge as inoculum. The experiment showed less fatty acid accumulation, increased production, and also a more stable process compared to the mono-digestion of FW. A review of all the scientific articles on behavior of food waste during the anaerobic digestion process from the year 2013 to 2015 was conducted, and. the study revealed that pretreated (thermally and chemically treated) food waste resulted in higher methane yield than the untreated food waste, and more than $18 \%$ of the research was performed by pretreating food waste (Komilis et al., 2017). In a study performed by Capson-Tojo et al. (2017), dry mono digestion of FW with the varying substrate to inoculum ratio $(0.25,0.5$ and 1$)$ and total solid content $(20 \%$ and $30 \%$ ), lower methane yield and longer lag period was observed at the higher substrate to inoculum ratio. Simultaneously, in the same experiment, co-digestion of the FW and cardboard paper was performed with the same parameters, which showed less acid accumulation and the small difference in yield obtained. Upon thorough research, the same authors concluded that the substrate and inoculum ratio was a major parameter in $A D$ of food waste, and $a$ lower substrate to the inoculum ratio resulted in inefficient methane production. At higher substrate to inoculum ratio, lower degradation of the substrate was observed resulting in hydrogen production ( Capson-Tojo et al., 2017). Liu et. al. (2009) studied the effect of feed to inoculum ratio by performing $A D$ of $F W$ in a $1 \mathrm{~L}$ batch reactor under controlled thermophilic and mesophilic conditions. The result suggested an inverse relation of feed to inoculum ratio and biogas yield. The greater yield was observed in the thermophilic condition under less feed to the inoculum ratio; the yield under mesophilic condition was quite lower than that obtained at thermophilic temperature. Previously carried out studies have shown that the alkalinity addition by varying inoculum and substrate ratio and lowering OLR could be the solution for successful anaerobic digestion of food waste in a controlled environment (Li et al., 2018; Liu et al., 2009). In contradiction, the trials of $A D$ of food waste in an ambient and uncontrolled condition were merely seen in the literature. This study aims to fill the gap between controlled laboratory and real field situations so that even the laboratory results could predict the real situation in the field.

In real situation, for the household biogas plant users in Nepal and in other developing countries, it is not viable to maintain controlled temperature as well as to undergo pretreatment of the feeding material and use cultured inoculum for the plant. In Nepal, the widely used household biogas plant, such as modified GGC 2047 and few urban household plants are not subjected to cultured inoculum start-up and are operated at ambient condition. Therefore, the implications derived from the experiments conducted under the temperature-controlled condition and with cultured inoculum for biogas production are not applicable for the majority of the Asian and African households. Such results rather mislead the estimation of biogas production potential in those settings. Hence, this study has been devised to assess the performance of anaerobic digestion of food waste in both batch and semi-continuous process with the addition of a variable percentage of uncultured inoculum (digestate obtained from operating household biogas plants) in an environment that exactly replicates the actual environment where the urban household digesters are being operated. This study also aims to reveal the challenges in the AD process of food waste when subjected to an uncontrolled environment and proposes ways to overcome those challenges.

\section{MATERIALS AND METHODS}

\subsection{Feed Materials}

Food waste was obtained from the Kathmandu University (KU) canteen located in Dhulikhel, Nepal. Wastes such as meat bones, lemon, and pickles were hand picked and thrown. Food waste was first ground with a food processor before using it for feed. The collected sample of food waste primarily consisted of cooked and uncooked vegetables along with cooked rice as depicted in Figure 1.

Digestate obtained from a functional household biogas plant treating cattle manure was used as inoculum for all the reactors. For each experiment, the inoculum was used in different proportions, measured by percent-weight of the substrate used such as $15 \%, 20 \%, 50 \%, 100 \%$, and $200 \%$.

\subsection{Design and Operation of Digesters}

The batch digestion tests were carried out in $500 \mathrm{ml}$ borosilicate bottles and were made airtight using rubber

\section{Composition of Food waste}

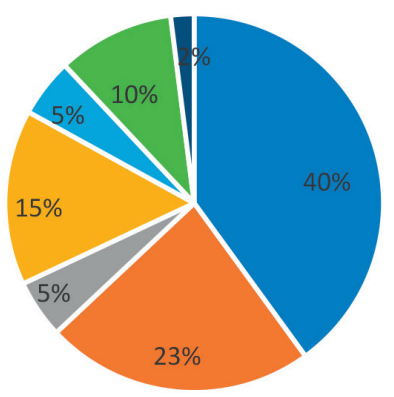

- rice - Brinjal | Dal | Carrot $\mid$ Peas - Potato - Papad

FIGURE 1: Composition of Food waste obtained from KU canteen. 


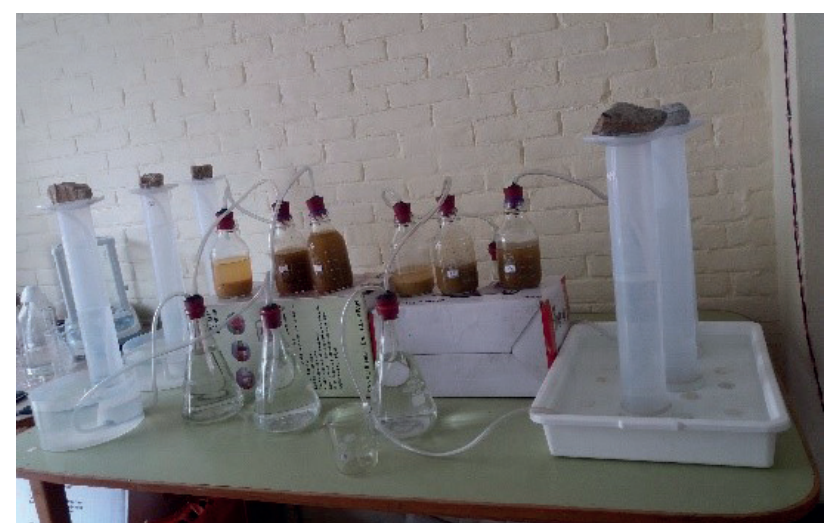

FIGURE 2: Picture of a batch reactors.

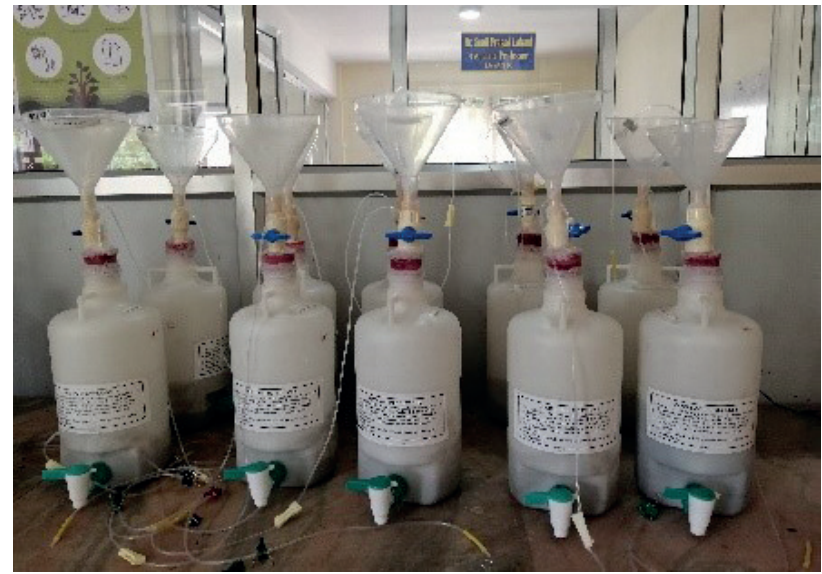

FIGURE 3: Picture of a semi-continuous reactors.

corks fitted with infusion sets (IV sets) as shown in Figure 2. The bottle was then connected to $\mathrm{NaOH}$ scrubber followed by water displacement setup. All the reactor bottles were kept at ambient conditions for the trials.

The semi-continuous digesters used were $5 \mathrm{~L}$ bottles which were used for the semi-continuous feeding and withdrawal of the digestate as shown in Figure 3. A rubber cork fitted with $1 / 2$ inch PVC pipe was attached to a plastic funnel for the inlet of the substrate. The infusion set was attached to the cork to work as gas outlet for the digester. Similar to the batch setup, all the components were sealed, and digester was made airtight.

The anaerobic digestion of the food waste in batch reactors was carried out in two different trials: (1) FW was independently digested as mono feed and with an inoculum of $20 \%$ weight of the substrate (2) FW with an in- oculum of $50 \%, 100 \%$ and $200 \%$ weight of the substrate in different reactors. $50 \mathrm{~g}$ of the substrate with $10 \%$ TS was added into each digester. Each batch test was run in duplicate and the test was carried out for 30 days in ambient temperature. The volume of the gas produced by each reactor was measured daily and the measurements of gas composition were analyzed 5 to 8 times during each experiment.

Two sets of semi-continuous digesters were fed with food waste to test for biogas production. Set 1 reactors were fed with food waste of $10 \%$ TS and set 2 reactors were fed with food waste of $6 \%$ TS. In both sets, $15 \%$ of inoculum was added to the weight of the substrate being used. For these reactors, two different OLR 1gVS/L.d and $1.8 \mathrm{gVS} / \mathrm{Ld}$ and hydraulic retention time of 50 days were used.

\subsection{Analytical methods}

Before experimentation, the substrates, and inoculum were characterized. The TS and VS content were determined using standard methods of the American Public Health Association(APHA, 2005). pH was measured using Exotech SOL $100 \mathrm{pH}$ meter. The biogas composition was measured with Sewerin Multitec-545 gas analyzer. The ambient temperature was recorded every half an hour to attribute to temperature fluctuation using temperature logger. The total organic carbon was measured using standard provided by the American Society of Agronomy and Soil Science and the total organic nitrogen was calculated using APHA 4500-Norg Macro- Kjeldahl method. Based on the readings of these instruments the $\mathrm{C} / \mathrm{N}$ ratio of the substrate was calculated.

\section{RESULT AND DISCUSSION}

\subsection{Physical and Chemical Properties of the sub- strate}

Table 1 shows the total solid, volatile solids, $\mathrm{pH}$, and total organic carbon to nitrogen $(\mathrm{C}: \mathrm{N})$ ratio of food waste, inoculum and feeding sample of different Substrate (S) to Inoculum (I) (S: I) ratio used for the different trials of this study. $\mathrm{pH}$ of all samples seems very acidic except $\mathrm{S}$ : I ratio $1: 1$ and $1: 2$, which indicates that a high inoculum ratio is required to increase the $\mathrm{pH}$ of the feed.

\subsection{Experimental trials in batch reactors}

Figure 4 shows the daily gas production and average temperature during the anaerobic digestion of food waste with $20 \%$ of inoculum added to it. The experiment was conducted from the second week of May to April 2019 and the

TABLE 1: Properties and characteristics of food waste and inoculum.

\begin{tabular}{|c|c|c|c|c|c|c|c|c|}
\hline \multirow{3}{*}{$\begin{array}{c}\text { Characteristics } \\
\text { TS\% }\end{array}$} & \multirow{3}{*}{$\begin{array}{c}\text { Food waste } \\
20.8\end{array}$} & \multirow{3}{*}{$\begin{array}{c}\text { Inoculum } \\
10.1\end{array}$} & \multicolumn{6}{|c|}{ Substrate(S) to inoculum (I) (S: I ratio) of the Sample } \\
\hline & & & \multicolumn{2}{|c|}{$15 \%(20: 3)$} & \multirow{2}{*}{$\begin{array}{c}\mathbf{2 0} \%(\mathbf{5 : 1 )} \\
10 \%\end{array}$} & \multirow{2}{*}{$\begin{array}{c}\mathbf{5 0} \%(\mathbf{2 : 1 )} \\
10 \%\end{array}$} & \multirow{2}{*}{$\begin{array}{c}100 \%(1: 1) \\
10 \%\end{array}$} & \multirow{2}{*}{$\begin{array}{c}\mathbf{2 0 0 \% ( 1 : 2 )} \\
10 \%\end{array}$} \\
\hline & & & $6 \%$ & $10 \%$ & & & & \\
\hline VS\% (of TS\%) & 89.2 & 60 & $84.9 \%$ & $86.4 \%$ & $83.5 \%$ & $74.8 \%$ & $81.9 \%$ & $80.5 \%$ \\
\hline $\mathrm{pH}$ & 4.4 & 7.1 & 5.2 & 5.2 & 5.8 & 6.13 & 6.30 & 6.57 \\
\hline C: N Ratio & 22.4 & 19.6 & 22.2 & 22.0 & 21.9 & 21.5 & 20.2 & 19.8 \\
\hline
\end{tabular}


figure presents the average ambient temperature range during the operation of batch reactors to be between 20$26^{\circ} \mathrm{C}$. A small amount of gas production was noted during the initial week that could be due to the inoculum. However, after the first week of operation, the production of gas stopped completely despite that the reactor was subjected to a very small fluctuation in temperature. Figure 5 shows the cumulative gas production during the process along with the average temperature trend.

The $\mathrm{pH}$ of the feed reduced from 5.78 to 3.32 after two weeks of the digestion process. The abrupt halt of the gas production might be due to acidification of the substrate and absence of the methanogenesis process during the digestion process.

Figure 6 shows the average temperature and gas production during anaerobic digestion of food waste added with $50 \%, 100 \%$ and $200 \%$ of inoculum to the weight of the substrate. This shows the production of gas in the initial few days; however, the production is drastically reduced thereafter. The highest value of daily gas production was obtained at 4- 6 days of operation in all the reactors. The average temperature during the operation of the $A D$ process was between $23-25^{\circ} \mathrm{C}$. The experiment was conducted from the last week of July to the first week of August 2019.

Figure 7 shows the cumulative gas production in this trail. It depicts that after the first week of operation, the gas production in all the reactors differed. A total of four gas composition measurements were taken during the experimental process which showed a negligible amount of methane production ( $\mathrm{CH} 4$ range of $0.1-0.7 \%$ ). During the first week of operation, the methane composition range of $0.1-0.3 \%$ was observed. After observing the process for 19 days, the reactors were discarded taking into consideration the result obtained from the gas analyzer $(0.7 \% \mathrm{CH} 4$ on the 19th day). The $\mathrm{pH}$ of the mixture before and after $A D$ in Table 2 shows souring of the feedstock inside the digester. This might be due to excessive accumulation of volatile fatty acid which resulted in a drastic reduction of $\mathrm{pH}$ of the substrate which might have led to halting the methanogenesis process during the AD process.

\subsection{Experimental trial in semi-continuous reactors}

Figure 8 illustrates the daily average temperature and gas production plot during anaerobic digestion of food waste at different total solid content in a semi-continuous reactor, observed at HRT of 50 days. The average temper-

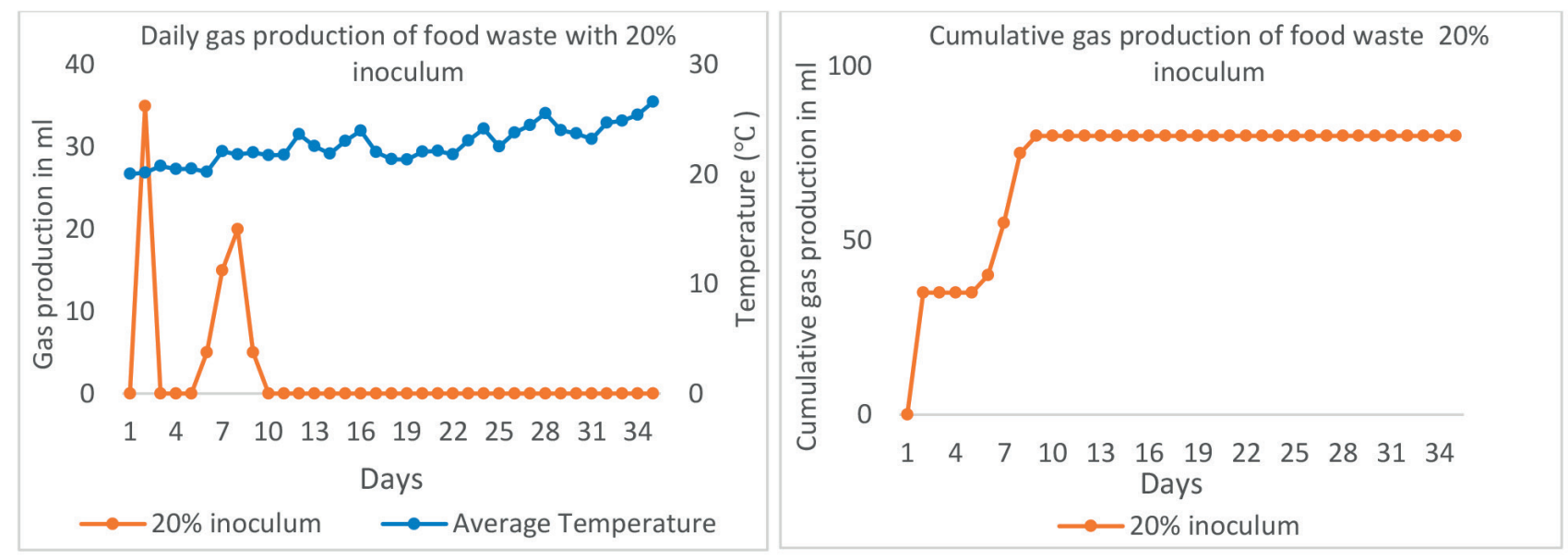

FIGURE 4 AND 5: Picture of a semi-continuous reactors.

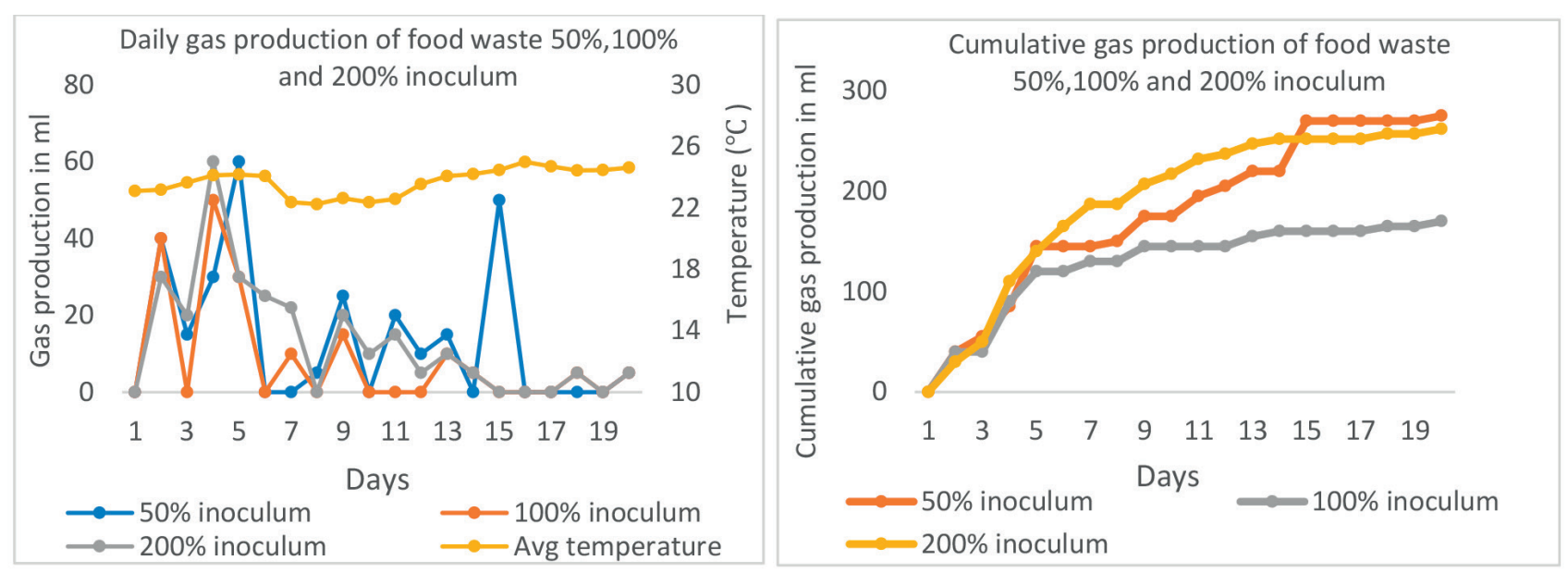

FIGURE 6 AND 7: Daily and cumulative gas production in trial 2 batch reactors. 
TABLE 2: $\mathrm{pH}$ of the mixture before and after $A D$.

\begin{tabular}{c|c|c|c|c} 
S. N & Reactor Bottle & pH before AD & PH after AD \\
\hline 1 & $200 \%$ & 6.57 & 4.41 \\
\hline 2 & $100 \%$ & 6.30 & 3.65 \\
\hline 3 & $50 \%$ & 6.13 & 2.89 \\
\hline
\end{tabular}

ature during the whole process was between $20-26^{\circ} \mathrm{C}$. The $A D$ of food waste was continued from the second week of May to July. Figure 9 shows the gas production in the reactor having food waste with $10 \%$. TS content seems to be higher than the reactor having food waste with $6 \%$ TS content. Though the feeding of the reactors was run at relatively low $\mathrm{pH}$, a considerable amount of gas production was observed in both the reactors. The maximum gas yield of $135.24 \mathrm{~L} / \mathrm{kgVS}$ was obtained from the $A D$ of food waste with $10 \%$ TS.

The result from the gas analyzer, however, proved the presence of a very small amount of methane gas. The results from the gas analyzer (8 times during the whole experimental session) showed $\mathrm{CH}_{4}$ range from 0.1 to $13 \%$. This suggests the inability of the growth of methanogens during the anaerobic digestion process. The inhibition might be created due to the souring of the reactor resulting from the rapid conversion of easily digestible food waste to VFA at the early stage of the digestion process along with low initial $\mathrm{pH}$ of the feed. $\mathrm{pH}$ observed after the anaerobic digestion process was 3.4. The experiment trials conducted in both batch and semi-continuous reactors suggest that there was rapid acidification in the process, limiting the methanogenesis step due to sudden $\mathrm{pH}$ drop. The low initial $\mathrm{pH}$ of the substrate, uncontrolled temperature, and unmixed condition could be vital factor for the growth of the methanogens during the process.

A similar study was conducted in Beijing, China using canteen food waste for investigating characteristics of food waste containing different substrates to inoculum (S: I) ratio $(0.5,0.6,0.7,0.8,1.0$, and 1.2$)$. In the experiment, it was observed that there was rapid acidification of the reactor as well as reduced biogas production with a higher
S: I ratio. Lower the substrate to the inoculum ratio, the high biogas conversion ratio was observed with a shorter lag phase (Li et al., 2018). In another similar experiment, S: I ratio of 1:2,1:1 and 2:1 were used which showed good stability and higher methane productivity in ratio 1:2; however, higher ratio such as 2:1 indicated higher conversion rates of VFA resulting in acidic slurry inside the reactor (Zhang et al., 2019). These findings justify the result obtained in trial 1 of this experiment (Figures 4 and 5) where a high S: I ratio of 5:1 was used, which caused the stoppage of gas production after few days of operation.

In all the experiments conducted by other researchers as indicated in the discussion and Table 3 , the trials were performed either incubated in shakers, maintaining mesophilic conditions or were performed in automatic methane potential system (Li et al., 2018; Zhang et al., 2019). Moreover, the inoculum used in most of the similar experiments was either control culture, seeded/inoculated, or pre-treated inoculum, which was observed to help in boosting the methanogenic activities inside reactors (Hobbs et al., 2018; Li et al., 2018; Rafieenia et al., 2018).

The trials in this study were conducted in an uncontrolled environment with uncultured inoculum and at ambient temperature. Therefore, even when varying the same substrate to the inoculum ratio as conducted in other experiments, a different result might have been obtained. The findings of this study is believed to fill the gaps in results achieved between controlled laboratory conditions and the real field condition so that the laboratory results could predict the real situation in the field to help design the program and policies. An example from Nepal Sahari Gharelu Biogas plant introduced in the year $2012 / 13$ by the government of Nepal as a pilot urban domestic biogas project in

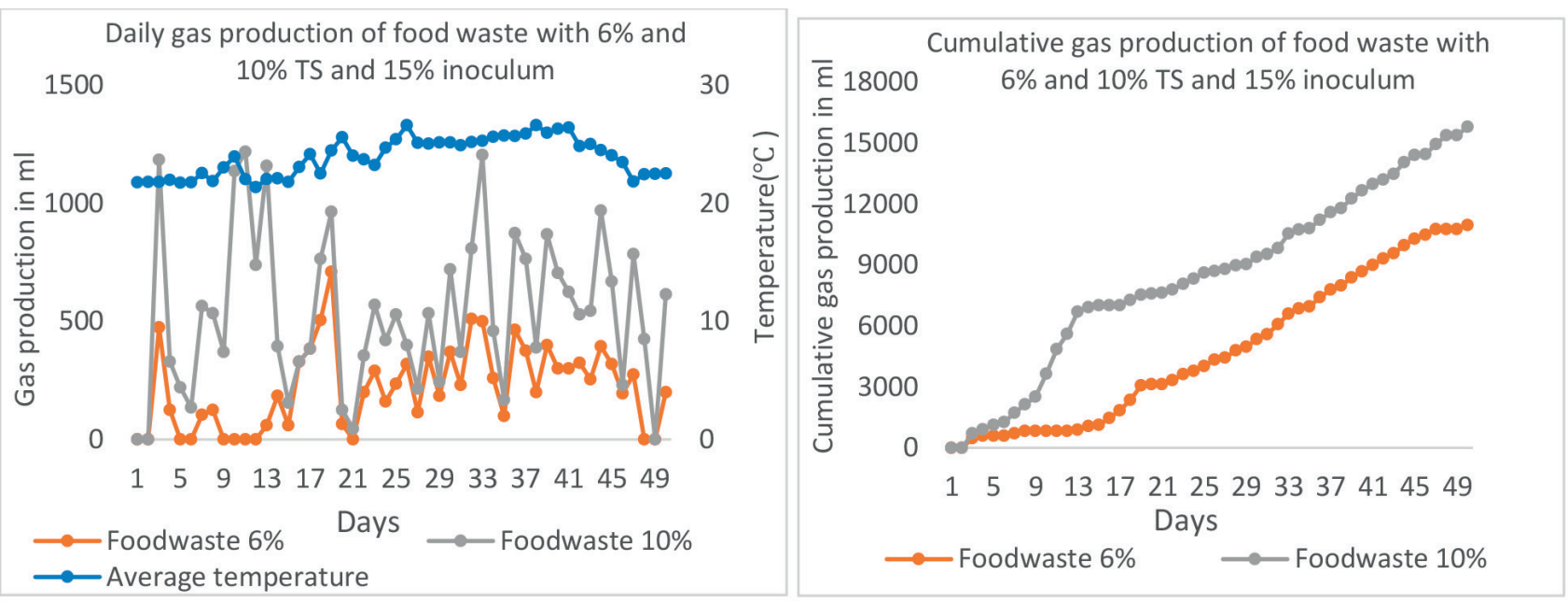

FIGURE 8 AND 9: Daily and Cumulative Gas production in trial 3 Semi-continuous reactors. 
TABLE 3: Comparison of the present study with other studies.

\begin{tabular}{|c|c|c|c|c|c|}
\hline Substrates(S) & Inoculum(I) & S: I ratio & Conditions & Remarks & References \\
\hline Food waste & $\begin{array}{l}\text { Poultry litter } \\
\text { Goat manure } \\
\text { Cow dung } \\
\text { Piggery dung } \\
\text { Rhinoceros dung }\end{array}$ & $\begin{array}{l}1.5: 1 \\
2: 1 \\
2: 1 \\
1.5: 1 \\
1.5: 1\end{array}$ & $\begin{array}{l}\text { Temperature main- } \\
\text { tained at } 30^{\circ} \mathrm{C} \text {, a stir- } \\
\text { ring provision added }\end{array}$ & $\begin{array}{l}\text { Shorter start-up time and high- } \\
\text { er methane production from } \\
\text { food waste inoculated with } \\
\text { cow dung at ratio } 2: 1\end{array}$ & Dhamodharan et. al., 2015 \\
\hline $\begin{array}{l}\text { Municipal solid } \\
\text { waste }\end{array}$ & $\begin{array}{l}\text { Sludge from meso- } \\
\text { philic continuously } \\
\text { stirred reactor tank } \\
\text { treating wastewater }\end{array}$ & $\begin{array}{l}200: 3,100: 3,50 \\
: 3,25: 3,4: 1,1: 1 \\
1: 2,1: 4\end{array}$ & $\begin{array}{l}\text { Reactors incubated at } \\
\text { temperature } 35 \pm 20^{\circ} \mathrm{C}\end{array}$ & $\begin{array}{l}\text { Accumulation of maximum } \\
\text { dissolved organic carbon } \\
\text { (DOC) at ratio } 25: 3 \text {, maximum } \\
\text { methane production and lower } \\
\text { DOC at ratio } 1: 2 \text { and above }\end{array}$ & Boulanger et al., 2012 \\
\hline Food waste & $\begin{array}{l}\text { Inoculum from a } \\
\text { mesophilic anaero- } \\
\text { bic digester treating } \\
\text { sewage sludge at } \\
\text { the wastewater treat- } \\
\text { ment plant }\end{array}$ & $1: 2,1: 3,1: 4$ & $\begin{array}{l}\text { food waste of different } \\
\text { particle size }(1 \mathrm{~mm} \text {, } \\
2 \mathrm{~mm}, 5 \mathrm{~mm}) \text {, } \\
\text { maintained mesophilic } \\
\text { temperature of } 37^{\circ} \mathrm{C} \\
\text { using the water bath }\end{array}$ & $\begin{array}{l}\text { S: I ratio of } 1: 3 \text { and } 1: 4 \text { sta- } \\
\text { bilized reactors for smaller } \\
\text { particle size }(1 \mathrm{~mm} \text { and } 2 \mathrm{~mm}) \\
\text { Reduced volatile fatty acid } \\
\text { accumulation and } 91 \% \text { re- } \\
\text { duction of lag time at ratio } 1: 3 \\
\text { Highest methane yield ob- } \\
\text { served at ratio } 1: 2\end{array}$ & Okoro-Shekwaga et. al., 2020 \\
\hline Food waste & $\begin{array}{l}\text { Mesophilic } \\
\text { anaerobic sewage } \\
\text { sludge from sludge } \\
\text { treatment plant }\end{array}$ & $\begin{array}{l}33: 100 \\
, 1: 2,1: 1,2: 1,4: 1\end{array}$ & $\begin{array}{l}\text { TS\% varied }-4.4 \% \text { and } \\
10.5 \% \text {, Temperature } \\
\text { maintained at } 37 \pm 1^{\circ} \mathrm{C} \text {, } \\
\text { agitated using shaker } \\
\text { at } 60 \mathrm{rpm}\end{array}$ & $\begin{array}{l}\text { High organic fraction in- } \\
\text { creased risk of acidification } \\
\text { but also contributed to high } \\
\text { methane, S: I ratio< } 0.33 \text { re- } \\
\text { sulted in higher methane yield }\end{array}$ & Kawai et al., 2014 \\
\hline Food waste & $\begin{array}{l}\text { Digestate from a } \\
\text { functional household } \\
\text { biogas plant treating } \\
\text { cattle manure }\end{array}$ & $\begin{array}{l}20: 3,5: 1,2: 1 \\
1: 1,1: 2\end{array}$ & $\begin{array}{l}\text { Ambient room tem- } \\
\text { perature of } 20-26^{\circ} \mathrm{C} \\
\text { TS\% of } 6 \%, 10 \%\end{array}$ & $\begin{array}{l}\text { Mono digestion of food waste } \\
\text { resulted in unstable process, } \\
\text { greater gas production in } 10 \% \\
\text { TS, however, negligible meth- } \\
\text { ane composition, varying S: I } \\
\text { ratio was not enough for the } \\
\text { stable AD process }\end{array}$ & This study \\
\hline
\end{tabular}

Kathmandu valley is worth evaluating. A total of 23 plants were disseminated as a pilot project to manage organic kitchen waste in urban and peri-urban regions. The size of the biogas plant was $1 \mathrm{~m}^{3}$ and was a floating drum type which is essentially an Appropriate Rural Technology Institute (ARTI) model biogas plant developed in India (AEPC, 2013). Unfortunately, this model could not gain popularity and was not able to gain acceptability in urban settings of Nepal. The reason for this plant failure was due to its performance; the plant was reported to be unable to function well and all users discarded it in Kathmandu valley (Lohani \& Fulford, 2017).

\subsection{Preliminary results of co-digestion of food waste}

Anaerobic co-digestion of food waste with sewage sludge and chicken litter is in progress in the author's laboratory at Dhulikhel, Nepal. The experiment is being performed in a $5 \mathrm{~L}$ semi-continuous reactor at ambient temperature. A semi-continuous digester is fed with sewage sludge, poultry litter, and food waste to test for the biogas production. The reactor is fed with sewage sludge, poultry litter, and food waste in a ratio of $2: 1: 1$ at $8 \%$ TS. For the reactor, OLR of $0.70 \mathrm{gVS} / \mathrm{L}$.d and hydraulic retention time of 50 days are used. The trial is duplicated for the accuracy of the result.

Figure 10 renders high gas production during the co-digestion of food waste when compared to the mono digestion result in figure 8 . Although high fluctuation of temperature is seen, the daily average production throughout the process is $800 \mathrm{ml}$ of gas. That is to infer, more stability is seen during the co-digestion of food waste with other substrates. Moreover, the gas composition observed up to the date shows the highest methane content of nearly $66 \%$.

\section{CONCLUSIONS}

In this study, biogas generation from food waste under the ambient condition was performed with different percentages of inoculum, and total solid content in both batches and semi-continuous reactors. In all the experiments, common type of problem was observed, that is, the inability of growth of methanogens to initiate the methanogenic process during the AD process. Hence, no methane was produced during the $\mathrm{AD}$ process, though, $\mathrm{CO}_{2}$ and other gases were observed. This suggests that food waste mixed with up to $200 \%$ by weight with inoculum at the batch process and food waste mixed with $15 \%$ by weight with inoculum at semi-continuous process does not help significantly in anaerobic digestion process at the ambient condition of temperature range from 20 to $26^{\circ} \mathrm{C}$. The instability was due to a large $\mathrm{pH}$ drop and the souring of the reactor. It can be concluded that mono-digestion of food

Daily gas production of food waste codigested with sewage and poultry litter

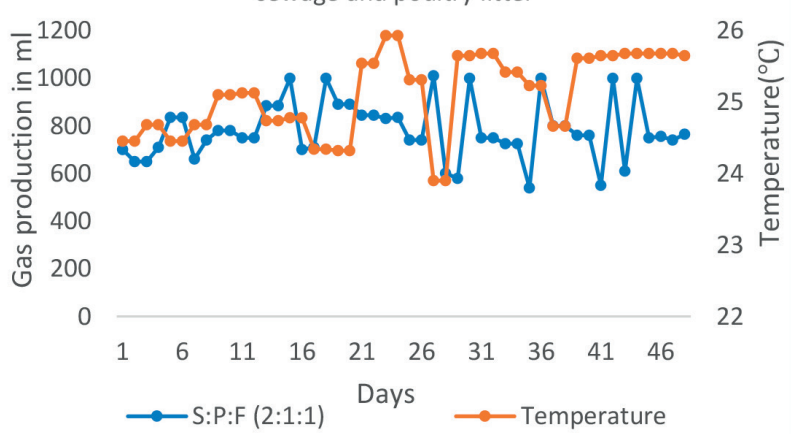

FIGURE 10: Daily gas production with co-digestion of food waste, sewage sludge, and poultry. 
waste and food waste with the addition of a few percentages of cow manure as inoculum was not enough for the stable biogas production. Co-digestion of food waste with a different substrate such as cow manure and urine, sewage sludge, poultry droppings could help balance $\mathrm{pH}$ and $\mathrm{C}$ : $\mathrm{N}$ ratio and nutrients in a favorable condition for the stable AD process and biogas production.

\section{ACKNOWLEDGMENT}

The authors would like to acknowledge Dr. Khagendra Acharya for his support in proofreading the manuscripts and the EnergizeNepal Project for the financial support of the biogas project (ENEP-RENP-II-18-01).

\section{REFERENCES}

AEPC, Urban Domestic Biogas, Altern. Energy Promot. Cent. (2013). https://www.aepc.gov.np/urban-domestic-biogas (accessed September 9, 2019).

APHA. (2005). Standard Methods for the Examination of Water and Wastewater. In American Public Health Association. Washington,DC.

Banks, C. J., Zhang, Y., Jiang, Y., \& Heaven, S. (2012). Trace element requirements for stable food waste digestion at elevated ammonia concentrations. Bioresource Technology, 104, 127-135. https:// doi.org/10.1016/j.biortech.2011.10.068

Boulanger, A., Pinet, E., Bouix, M., Bouchez, T., \& Mansour, A. A. (2012). Effect of inoculum to substrate ratio (I/S) on municipal solid waste anaerobic degradation kinetics and potential. Waste Management, 32(12), 2258-2265. https://doi.org/10.1016/j.wasman.2012.07.024

Capson-Tojo, G, Rouez, M., Crest, M., Trably, E., Steyer, J.-P., Delgenès, J.-P., \& Escudié, R. (2017). Optimization of urban food waste valorization: cardboard as suitable co-substrate for dry anaerobic co-digestion. The 15th World Congress on Anaerobic Digestion, (October).

Capson-Tojo, Gabriel, Trably, E., Rouez, M., Crest, M., Steyer, J. P., Delgenès, J. P., \& Escudié, R. (2017). Dry anaerobic digestion of food waste and cardboard at different substrate loads, solid contents and co-digestion proportions. Bioresource Technology, 233, 166175. https://doi.org/10.1016/j.biortech.2017.02.126

Dhamodharan, K., Kumar, V., \& Kalamdhad, A. S. (2015). Effect of different livestock dungs as inoculum on food waste anaerobic digestion and its kinetics. Bioresource Technology, 180, 237-241. https://doi.org/10.1016/j.biortech.2014.12.066

H. M. El-Mashad, J. A. McGarvey, \& R. Zhang. (2008). Performance and Microbial Analysis of Anaerobic Digesters Treating Food Waste and Dairy Manure. Biological Engineering, 1(3), 233-242. https:// doi.org/10.13031/2013.25332

Hobbs, S. R., Landis, A. E., Rittmann, B. E., Young, M. N., \& Parameswaran, P. (2018). Enhancing anaerobic digestion of food waste through biochemical methane potential assays at different substrate: inoculum ratios. Waste Management, 71, 612-617. https://doi.org/10.1016/j.wasman.2017.06.029

Huete, E., de Gracia, M., Ayesa, E., \& Garcia-Heras, J. L. (2006). ADM1based methodology for the characterisation of the influent sludge in anaerobic reactors. Water Science and Technology, 54(4), 157166. https://doi.org/10.2166/wst.2006.537

Kawai, M., Nagao, N., Tajima, N., Niwa, C., Matsuyama, T., \& Toda, T. (2014). The effect of the labile organic fraction in food waste and the substrate/inoculum ratio on anaerobic digestion for a reliable methane yield. Bioresource Technology, 157, 174-180. https://doi. org/10.1016/j.biortech.2014.01.018

Komilis, D., Barrena, R., Grando, R. L., Vogiatzi, V., Sánchez, A., \& Font, $X$. (2017). A state of the art literature review on anaerobic digestion of food waste: influential operating parameters on methane yield. Reviews in Environmental Science and Biotechnology, 16(2), 347-360. https://doi.org/10.1007/s11157-017-9428-z
Li, Y., Jin, Y., Borrion, A., \& Li, J. (2018). Influence of feed/inoculum ratios and waste cooking oil content on the mesophilic anaerobic digestion of food waste. Waste Management, 73, 156-164. https:// doi.org/10.1016/j.wasman.2017.12.027

Lin, C. S. K., Pfaltzgraff, L. A., Herrero-Davila, L., Mubofu, E. B., Abderrahim, S., Clark, J. H., ... Luque, R. (2013). Food waste as a valuable resource for the production of chemicals, materials and fuels. Current situation and global perspective. Energy and Environmental Science, 6(2), 426-464. https://doi.org/10.1039/c2ee23440h

Liu, G., Zhang, R., El-Mashad, H. M., \& Dong, R. (2009). Effect of feed to inoculum ratios on biogas yields of food and green wastes. Bioresource Technology, 100(21), 5103-5108. https://doi. org/10.1016/j.biortech.2009.03.081

Lohani, Sunil P., \& Havukainen, J. (2018). Anaerobic Digestion: Factors Affecting Anaerobic Digestion Process. 343-359. https://doi. org/10.1007/978-981-10-7413-4_18

Lohani, Sunil Prasad, Wang, S., Lackner, S., Horn, H., Khanal, S. N., \& Bakke, R. (2016). ADM1 modeling of UASB treating domestic wastewater in Nepal. Renewable Energy, 95, 263-268. https://doi. org/10.1016/j.renene.2016.04.014

Morales-polo, C., Cledera, M., \& Soria, B. Y. M. (2018). Reviewing the Anaerobic Digestion of Food Waste : From Waste Generation and Anaerobic Process to Its Perspectives. https://doi.org/10.3390/ app8101804

Okoro-Shekwaga, C. K., Turnell Suruagy, M. V., Ross, A., \& Camargo-Valero, M. A. (2020). Particle size, inoculum-to-substrate ratio and nutrient media effects on biomethane yield from food waste. Renewable Energy, 151, 311-321. https://doi.org/10.1016/j. renene.2019.11.028

Posmanik, R., Labatut, R. A., Kim, A. H., Usack, J. G., Tester, J. W., \& Angenent, L. T. (2017). Coupling hydrothermal liquefaction and anaerobic digestion for energy valorization from model biomass feedstocks. Bioresource Technology, 233, 134-143. https://doi. org/10.1016/j.biortech.2017.02.095

Rafieenia, R., Pivato, A., \& Lavagnolo, M. C. (2018). Effect of inoculum pre-treatment on mesophilic hydrogen and methane production from food waste using two-stage anaerobic digestion. International Journal of Hydrogen Energy, 43(27), 12013-12022. https://doi. org/10.1016/j.ijhydene.2018.04.170

Sawatdeenarunat, C., Surendra, K. C., Takara, D., Oechsner, H., \& Khanal, S. K. (2015). Anaerobic digestion of lignocellulosic biomass: Challenges and opportunities. In Bioresource Technology (Vol. 178). https://doi.org/10.1016/j.biortech.2014.09.103

Xia, A., Cheng, J., \& Murphy, J. D. (2016). Innovation in biological production and upgrading of methane and hydrogen for use as gaseous transport biofuel. Biotechnology Advances, 34(5), 451-472. https://doi.org/10.1016/j.biotechadv.2015.12.009

$\mathrm{Xu}, \mathrm{F}$., \& Li, Y. (2017). Anaerobic digestion of food waste - Challenges and opportunities Bioresource Technology Anaerobic digestion of food waste - Challenges and opportunities. Bioresource Technology, 247(December), 1047-1058. https://doi.org/10.1016/j. biortech.2017.09.020

Zamanzadeh, M., Hagen, L. H., Svensson, K., Linjordet, R., \& Horn, S. J. (2017). Biogas production from food waste via co-digestion and digestion- effects on performance and microbial ecology. Scientific Reports, 7(1), 1-12. https://doi.org/10.1038/s41598-017-15784-w

Zhang, C., Su, H., Baeyens, J., \& Tan, T. (2014). Reviewing the anaerobic digestion of food waste for biogas production. Renewable and Sustainable Energy Reviews, 38, 383-392. https://doi. org/10.1016/j.rser.2014.05.038

Zhang, C., Xiao, G., Peng, L., Su, H., \& Tan, T. (2013). The anaerobic co-digestion of food waste and cattle manure. Bioresource Technology, 129, 170-176. https://doi.org/10.1016/j.biortech.2012.10.138

Zhang, J., Wang, Q., Zheng, P., \& Wang, Y. (2014). Anaerobic digestion of food waste stabilized by lime mud from papermaking process. Bioresource Technology, 170, 270-277. https://doi.org/10.1016/j. biortech.2014.08.003

Zhang, W., Li, L., Xing, W., Chen, B., Zhang, L., Li, A., ... Yang, T. (2019). Dynamic behaviors of batch anaerobic systems of food waste for methane production under different organic loads, substrate to inoculum ratios and initial $\mathrm{pH}$. Journal of Bioscience and Bioengineering, 128(6), 733-743. https://doi.org/10.1016/j.jbiosc. 2019.05 .013 